\title{
Når ryggmargen skades
}

Ryggmargsskader forekommer heldigvis sjelden, men for dem som rammes, endres ofte livet radikalt. I dette nummer av Tidsskriftet starter en serie artikler som omhandler ulike aspekter ved denne type skade. En slik temaserie er viktig fordi ryggmargsskadede har en lang rekke mulige varianter av senfølger hvilket gjør det nødvendig med rehabilitering og livslang oppfølging i spesialiserte rehabiliteringsklinikker. Dagens tilbud til ryggmargsskadede er basert på internasjonale anbefalinger. Disse ivaretas av spinalenhetene som sikrer pasientene en behandling og rehabilitering som holder god internasjonal standard. Det er viktig at denne kompetansen opprettholdes og at ikke miljøene splittes. Noen senfølger dekkes av denne serien, andre er belyst i Tidsskriftet tidligere, slik som autonom dysrefleksi, seksuelle forstyrrelser og metabolske forandringer. Som temaserien viser har pasientene behov for tjenester fra mange spesialiteter.

En traumatisk ryggmargsskade er definert som en akutt, traumatisk lesjon av ryggmargen med varierende grad av motoriske og/eller sensoriske utfall.Definisjonen inkluderer skader på cauda equina, men ekskluderer isolerte skader av andre nerverøtter. Ryggmargsskade forekommer hyppigst i de fleksible delene av ryggraden, dvs. cervikalt og lumbalt. De vanligste årsaker til traumatisk ryggmargsskade er fall, trafikkulykke, arbeidsskade, idrettsskade eller vold. Skaden kan også oppstå iatrogent, som følge av medisinsk eller kirurgisk behandling.

Pasientene har ofte svært sammensatte plager. I tillegg til ulike grader av lammelser og sensibilitetstap kan pasienten ha utfordringer som smerter, spastisitet, autonome forstyrrelser og trykksår. Ryggmargsskader medfører dessuten helseproblemer fra ulike organsystemer, og personene vil kunne ha økonomiske, sosiale og psykologiske problemer på grunn av endret funksjonsnivå, tap av arbeid, samt ombygging eller bytte av bolig. Det er derfor spesielt viktig at leger og helsepersonell som har kontakt med disse har kunnskap om ryggmargsskader når de møter denne pasientgruppen.

Forekomsten av ryggmargskader forårsaket av trafikkulykker har $ø k t$ de senere år, spesielt blant menn under 30 år. I den andre enden av aldersskalaen ser vi en økt forekomst av fallrelaterte skader og inkomplette nakkeskader (1). Samtidig har det de senere tiår vært en dramatisk reduksjon i tidlig død hos denne pasientgruppen noe som øker prevalensen av ryggmargsskader.

Basalforskningen er rettet mot ulike strategier for reparasjon av ryggmargen. Det er fortsatt lenge til dette kan bli et reelt behandlingstilbud. Innenfor klinisk forskning arbeides det med å se på hvilke fysiske rehabiliteringstiltak som best kan gjenopprette funksjon og mobilitet.

Rehabilitering av pasienter med ryggmargsskade representerer helt spesielle utfordringer for behandlingsapparatet. Dette gir pasientene en selvstendighet og økt livskvalitet. Behandling og rehabilitering foregår i dag ved de tre spinalenhetene, som er lokalisert til Sunnaas sykehus, St. Olavs hospital og Haukeland universitetssykehus. Spinalenhetene har ansvaret for livslang spesialisert oppfølging. Et team av ulike yrkesgrupper samarbeider tett med pasienten selv og dennes familie, inkludert lege, sykepleier, fysioterapeut, ergoterapeut, psykolog, sosionom og brukerkonsulent. Ofte er det behov for omskolering og fysisk tilrettelegging i hjemmet. I rehabiliteringen spiller pasientene selv også en avgjørende rolle, idet de utgjør en viktig ressurs for hverandre. Haukeland universitetssykehus har landsfunksjon for funksjonsforbedrende håndkirurgi. Ved senetransposisjon kan pasientene få bedret håndfunksjon som gir dem økt selvstendighet.

Det er en utfordring å planlegge, dimensjonere og tilrettelegge for en adekvat, helhetlig og sammenhengende tiltakskjede for denne pasientgruppen også utenfor spinalenhetene, og det krever mye og sammensatt kunnskap. Aller viktigst er det selvsagt å forhindre at ryggmargsskade overhodet skjer. Arbeid for å øke bevisstheten om fare ved skader, særlig til utsatte grupper, har gitt resultater. Med en økende andel eldre $\mathrm{i}$ befolkningen vil forebygging av fall i denne aldersgruppen få større betydning både praktisk og samfunnsøkonomisk. Regelmessig mosjon, treningsprogam, synssjekk, gjennomgang av medikamentene og forbyggende tiltak hjemme kan gi store gevinster.

Den høyeste forekomsten av traumatisk ryggmargsskade finner vi hos ungdom. I USA har video med ryggmargsskadet ungdom som forteller om hvordan de ble skadet og informerer om hvordan man kan unngå ulykker, redusert antall ulykker blant skoleelever. I Norge har Sunnaas sykehus og Landsforeningen for Ryggmargsskadde (LARS) laget kampanjefilmen «tenker på deg» som setter søkelyset på trafikksikkerhet blant yngre (www.tenkerpadeg.no), samt en Facebook-side.

Dagens pasienter med ryggmargsskader er kunnskapsrike og bruker Internett og sosiale medier aktivt. De er oppdatert på det siste innen forskning og behandling og informerer hverandre. De er eksperter på sin nye kropp og på nye kompenserende funksjoner. Både fastleger og helsepolitikere må lytte til hva pasientene sier. Fastlegen må ta kontakt med den spinalenheten som pasienten «tilhører» dersom det dukker opp nye plager som ikke umiddelbart kan behandles, ved økt funksjonstap eller noen form for usikkerhet.

\section{Ellen Merete Hagen}

ellen.merete.hagen@helse-bergen.no

Tiina Rekand

Marit Grønning

Ellen Merete Hagen (f. 1962) er ph.d. og spesialist i nevrologi og i samfunnsmedisin, med doktorgrad om epidemiologi ved traumatiske ryggmargsskader. Hun er postdoktor ved Universitetet i Bergen. Forfatter har fylt ut ICMJE-skjemaet og oppgir ingen interessekonflikter.

Tiina Rekand (f. 1960) er dr.med. og spesialist i nevrologi. Hun er overlege ved Spinalenheten, Nevrologisk avdeling, Haukeland universitetssykehus. Forfatter har fylt ut ICMJE-skjemaet og oppgir ingen interessekonflikter.

Marit Grønning (f. 1955) er dr.med. og spesialist i nevrologi. Hun er overlege ved Yrkesmedisinsk avdeling. Haukeland universitetssykehus og professor ved Universitet i Bergen.

Forfatter har fylt ut ICMJE-skjemaet og oppgir ingen interessekonflikter.

\section{Litteratur}

1. Hagen EM, Eide GE, Rekand T et al. A 50-year follow-up of the incidence of traumatic spinal cord injuries in Western Norway. Spinal Cord 2010; 48: 313-8. 